УДК $811.111 ’ 366.587$

DOI https://doi.org/10.26661/2414-1135-2021-82-10

\title{
ДОКОНЕЧНІСТЬ ЯК ПЕРЕКОНЛИВИЙ ПРИМУС У СЕМАНТИЧНІЙ СТРУКТУРІ АНГЛІЙСЬКОГО РЕЧЕННЯ 3 ПРЕДИКАТОМ FОRСЕ
}

\author{
Дерев'янко О. А. \\ кандидат філологічних наук, дочент, \\ доцент кафедри англійської філологіі \\ Прикарпатський національний університет імені Василя Стефаника \\ вул. Шевченка, 57, Івано-Франківськ, Украӥна \\ orcid.org/0000-0001-5645-6929 \\ oksana.derevianko@pnu.edu.ua
}

\begin{abstract}
Ключові слова: семантичний синтаксис, дебітивна модальність, каузатив, примушування, суб'єкт.
\end{abstract}

У статті проаналізовано специфіку каузативних дієслів як одного 3 основних засобів вираження дебітивної модальності. Серед значень каузативної семантики дієслова виокремлюємо значення примусу. Примус аналізуємо як зумовлену кимось або чимось необхідність діяти певним чином, усупереч волі, бажанню чи спрямування власних зусиль на виконання чого-небудь незалежно від бажання. Каузативна ситуація примусу включає відношення каузації, котре робить каузацію каузативною; каузатора; об'єкт каузації і стан об'єкта каузації. Уважаємо доречною класифікацію предикатів примусової дії, у якій вирізняються предикати переконливого примусу, настійності, нагальності; предикати заохочувального примусу; примусу 3 елементами погрози чи залякування; предикати отримання інформації за допомогою примусу; предикати соціально або службово обумовленого примусу; предикати підпорядкування та предикати самопримусу. До предикатів переконливого примусу, настійної наполегливості, нагальності/доконечності виконання дії відносимо такі лексеми: to force, cajole, cause, coax, compel, constrain, convince, drag, drive, impose, induce, influence, make, oblige, persuade, push, thrust, wheedle, wring тощо. Основним засобом вираження семантики примусу є предикат to force. У статті проаналізовано зазначену лексему на основі тлумачних словників, досліджено семантичну структуру англійського речення 3 предикатом to force; визначено детермінуючі чинники ситуації примусу. Предикат примусу to force має негативну конотацію, що пояснює небажаність, неготовність суб'єкта виконувати певну дію, тобто дія суперечить його волі, інтересам, тому в реченнях із предикатом to force $\epsilon$ лексеми, які вказують на вимушену дію, пояснюють небажання ii виконання, примушеність суб'єкта до іiі здійснення, тобто семантичний відтінок внутрішнього протистояння, негативного ставлення до дії може позначатися в контексті за допомогою слів із негативною семантикою. 


\title{
URGERCY AS A COMPELLING COERCION IN THE SEMANTIC STRUCTURE OF THE ENGLISH SENTENCE WITH THE PREDICATE FORCE
}

\author{
Derevianko O. A. \\ Candidate of Philological Sciences, Associate Professor, \\ Associate Professor at the Department of Foreign Languages \\ Vasyl Stefanyk Precarpathian National University \\ Shevchenko str., 57, Ivano-Frankivsk, Ukraine \\ orcid.org/0000-0001-5645-6929 \\ oksana.derevianko@pnu.edu.ua
}

Key words: semantic syntax, debitive modality, causative, coercion, subject.

\begin{abstract}
The article analyzes the specifics of causative verbs as one of the main means of expressing debitive modality. Among the meanings of the causative semantics of the verb is the meaning of coercion. Coercion is analyzed as the need to act in a certain way, contrary to the will, desire, caused by someone or something; direction of our own efforts to do something regardless of our desire. The causative situation of coercion includes a causal relationship that makes causation causative; causator; the object of causation and the state of the causative object. We consider it appropriate to classify the predicates of coercion into the predicates of convincing coercion, infusion; predicates of stimulating coercion; coercion with elements of threats and intimidation; predicates of obtaining information by coercion; predicates of socially or officially agreed coercion; predicates of subordination and predicates of selfcompulsion. To the predicates of convincing coercion, constant persistence, urgency of action the following lexemes can be referred: to force, cajole, cause, coax, compel, constrain, convince, drag, drive, impose, induce, influence, make, oblige, persuade, push, thrust, wheedle, wring and others.

The main means of expressing the semantics of coercion is the predicate to force. The article analyzed the specified lexeme based on the interpretive dictionaries. In the article the semantic structure of an English sentence with the predicate to force is investigated; the determining factors of the situation of coercion are determined. The predicate of coercion to force has a negative connotation, which explains the unwillingness of the subject to perform a certain action. Thus sentences with the predicate to force contain lexemes that indicate forced action, explain the reluctance to perform it, the subject's compulsion to do it, so the semantic shade of internal opposition, negative attitude to the action can be indicated in the context by words with negative semantics.
\end{abstract}

Постановка проблеми. Оскільки концепт примусу - складний і багатоаспектний феномен, котрий утворює невід'ємну частину суспільної комунікації, регулює взаємини людей у різноманітних ситуаціях i на різних соціальних рівнях, то вивчення мовних засобів його вираження не викликає сумніву. Під примусом розуміємо необхідність діяти певним способом незалежно від бажання, волі. Термін «примушування» ж позначає вимагання від кого-небудь виконання чогось незалежно від його волі, бажання; тобто «домагатися чого-небудь, застосовуючи силу; викликати у кого-небудь якусь дію, вчинок» [1, с. 940]. Каузативна семантика дієслова, на думку А. Кожокіної, містить значення спонукання, примушування, впливу, спрямовані каузатором на об'єкт каузації, щоб той здійснив певні дії, перейшов у певний стан [4, с. 231].

Каузативні дієслова були у фокусі уваги таких багатьох лінгвістів (Н. Арутюнова (1976), А. Аматов (2003), В. Богданов (1977), Н. Болдирев (2009), М. Всеволодова (2008), В. Гречко (1985), I. Долініна (1991), Г. Дистанова (2010), Є. Корді (2004), М. Сельванова (2005), Г. Сильницький (2006), Ю. Терешина (2008), А. Чудінов (1990), С. Шустова (2011), Т. Ященко (2008), D. Dowty (1972), S. Enzinger (2009), A. Goldberg (2006), I. Lyons (1996), L. Reed (1992) та ін.). Різні види каузативів проаналізовано на матеріалі різних мов, зокрема морфологічний каузатив - в англійській, німецькій, голландській, турецькій, українській, японській, індонезійській тощо (У. Басс, 
T. Градська, Г. Корнілов, А. Холодович, Л. Шарифова, С. Шустова, С. Яхонтов, J. Goldsmith, D. Dowty, T. Givon, B. Levin, R. Malka, J. Mattisof, K. Zimmer та ін.), аналітичний каузатив - в англійській (Т. Бородіна, Г. Лифар, W. Hollmann), французькій (Т. Абросімова, Ю. Ачаповська, Е. Корді, L. Reed, A. Rouveret) мовах, семантику каузативних конструкцій у російській мові описано в працях Т. Булініної, А. Шмелева, Г. Плаксіної, M. Shapiro та киргизькій мові (Т. Абдієв).

На нашу думку, специфіку семантики каузативних дієслів розкрито в працях Н. Арутюнової, В. Недялкова, Г. Сильницького, С. Кацнельсона, А. Чудінова. Різні класифікації каузативних дієслів запропоновано Н. Арутюновою, С. Назаровим, В. Недялковим, Г. Сильницьким; специфіку граматичних особливостей функціонування каузативних дієслів репрезентовано М. Всеволодовою, І. Долініною, С. Корді та ін.

Уважаємо, що каузативна ситуація примусу включає відношення каузації, котре робить каузацію каузативною; каузатора; об'єкт каузації і стан об'єкта каузації. За семантичною ознакою каузативні дієслова змушуваності, які становлять невід'ємну частину дебітивної модальності, на думку В. Храковського, репрезентують фактитивний вид дієслівної каузації (імпульс каузації йде від агенса) [9, с. 126], наприклад: наказати, веліти, примусити, заборонити тощо.

Оскільки предикати примусу вважаємо неоднорідними за значеннями, то розмежовуємо три групи дієслів примусу:

1) каузативні дієслова (to compel, to force тощо);

2) дієслова, які містять сему мовлення (to command, to persuade, to order тощо);

3) дієслова, що використовуються в каузативній функції як результат їх «перекатегоризації» (to have, to make, to get тощо).

Дієслова to have, to make, to get тощо вважаються службовими, функціонально-граматичними каузативами [2, с. 90-95]. Цілком зрозуміло, що семантикою службових дієслів не передбачено каузативної функції, тобто вона з'являється внаслідок їх постійного використання в певних синтаксичних умовах. Що стосується дієслів, котрі включають сему мовлення (to command, to persuade тощо), то А. Рейдель розмежовує дієслова, що позначають просту каузативність (суб'єкт тільки спонукає, а не діє сам) та ускладнену каузативність, дієслова якої висловлюють думку, що суб'єкт діє і спонукає об'єкт виконати дію чи вступити в новий стан [6, с. 6-7]. До першої групи відносяться, крім одиниць із найбільш широкою семантичною структурою (to force, cause, make), дієслова to order, command, instruct, не аналізуючи останні як каузативи із семою 'спосіб впливу'.
Дієслова типу to coax, bully A. Рейдель зараховує до другої групи, уважаючи, що вони виражають ситуацію, у якій суб'єкт діє сам і спонукає об'єкт до дії $[6$, с. 6-7].

Низка вчених (Є. Бєляєва, О. Дерев'янко, Г. Золотова, Є. Корді, Р. Westney та ін.) указує на те, що модальний компонент значення повинності, необхідності, який обов'язково присутній у структурі предикатів примусу, пов' язаний із семою каузації. Лінгвісти акцентують на тому, що дієслова примусу містять у структурі модальний компонент 'волевиявлення' як один із основних, базових модальних значень, хоча й називають його по-різному. Г. Золотова називає їх «каузативно-модальні дієслова», Є. Беляєва - «модальні модифікатори», В. Карасик - «модалізовані дієслова», бо вони займають проміжне місце між модальними й немодальними дієсловами.

Зрозуміло, що семема «волевиявлення» розрізняється в значенні багатьох дієслів. Згідно зі спостереженнями А. Опари, в англійській мові існують сто вісімнадцять дієслів, що приєднують інфінітив, із яких лише тридцять три дієслова містять сему волевиявлення, серед них - demand, designate, force, pressurize тощо [5, с. 10]. Значення волітивності також допускає градуальне варіювання (від негативно сильного до позитивно сильного). Незважаючи на велику кількість праць, об'єктом дослідження яких є каузативні дієслова, модальні дієслова дебітивності, очевидно, що немає одностайної думки лінгвістів щодо семантики каузативних дієслів, місця концепту примусу в дебітивній модальності, засобів вираження семантики примусу в англійській мові.

Мета й завдання статті. Мета статті полягає в аналізі семантичної структури англійського речення 3 предикатом примусу to force. Мета передбачає 3'ясування завдань, а саме: засобів вираження семантики примусу, впливу каузації на формування семантики примусу й опис семантики предикатів переконливого примусу.

Предмет та об'скт дослідження. Предметом дослідження $€$ особливості відтворення семантики примусу в англомовному дискурсі. Об'єктом аналізу є семантико-синтаксична структура речення з предикатом примусу to force.

Виклад основного матеріалу дослідження. Уважаємо, що в англійській мові семантику примусу до дії (змушуваності до їі виконання) позначають такі дієслова: bid, bludgeon, browbeat, bulldoze, bully, cajole, call on, capture, cause, cheer, claim, coax, coerce, command, compel, con, constrain, convince, cow, decree, demand, designate, dictate, direct, dragoon, drive, force, get, have, encourage, enforce, enjoin, entice, exact, extort, extract, impel, impose, incite, induce, influence, insist, instigate, intimidate, invoke, 
make (somebody do something), motivate, oblige, order, persuade, prescribe, press, prompt, push, require, seduce, squeeze, stimulate, tempt, thrust, wring, wheedle, worm тощо. Диференційною ознакою зазначених предикатів $\epsilon$ спільна сема 'примусова дія'.

Слушною видається класифікація предикатів примусової дії на предикати переконливого примусу, настійності, нагальності; предикати заохочувального (стимулюючого) примусу; примусу 3 елементами погрози чи залякування; предикати отримання інформації за допомогою примусу; предикати соціально/службово обумовленого примусу; предикати підпорядкування та предикати самопримусу [7].

Так, до предикатів переконливого примусу, настійної наполегливості, нагальності, доконечності виконання дії відносимо такі лексеми: to force, cajole, cause, coax, compel, constrain, convince, drag, drive, impose, induce, influence, make, oblige, persuade, push, thrust, wheedle, wring тощо.

Основним засобом вираження семантики примусу, на нашу думку, є предикат to force. Проаналізуємо зазначену лексему на основі тлумачних словників (Oxford Advanced Learner's Dictionary 1980, Webster Universal College Dictionary 1997). Так, Webster Universal College Dictionary тлумачить дієслівну лексему to force так:

To force - to compel, constrain, or oblige (oneself or someone) to do something; to drive or propel against resistance; to bring about or effect by force; to bring about of necessity or as a necessary result; to put or impose (something or someone) forcibly on or upon a person; to use force upon [12, c. 315-316].

Oxford Advanced Learner's Dictionary подає такі дефініції, у яких лексема to force позначає примус: compel, oblige; use force to get or to do something; to make sb do sth; break open by using force [11, c. 341].

Зрозуміло, що ситуація примусу включає такі елементи: детермінуючий чинник, те, що зумовлює необхідність виконання дії; об'єкт - той, кого примушують, на кого спрямований вплив детермінуючого чинника; ознака, тобто каузована дія або стан, які очікуються від агенса в результаті впливу детермінуючого чинника [3, с. 328-329].

$\mathrm{y}$ реченнях із предикатом примусу суб'єктом-каузатором $€$ :

1) назви осіб за професією, родом занять, соціальним статусом тощо, як-от: If your new boss forces you to leave deliberately making your life hell you can claim (The Daily Mirror), The raider forced him to open the safe and fled with cash (Northern Echo);

2) іменники, що позначають явища природи, натурфакти (night, day, autumn, rain, lightning тощо): An imperceptible breeze forced the leaves of a regiment of birch trees into anxious quaking (E. Taylor); A January wind forced an entry through the legs of the law-eargerly sniffed the corner of the hall (M. Caine); Bad weather forced the cancellation of the fly-past (The East Anglian);

3) подвійні суб'єкти, коли $\mathrm{S}_{1}$ i $\mathrm{S}_{2}$ збігаються, так звана «зворотна каузація» (коли суб'єкту доводиться докладати зусилля щодо самого себе): For a time her emotions stopped her thinking clearly until she forced herself to concentrate on the problem logically (K. McCallum); Glad to be alone in her familiar little room later, Leonora forced herself to face the indigestible truth (C. George).

4) абстрактні іменники, що позначають властивості, поняття, процеси, пов'язані з відчуттями й почуттями (feeling, violence тощо): His abuse beat in her face like rain so heavy that it forced shut her eyes (G. McCaughrean); Hate him as she might for his intractability, sheer common sense forced her to agree with him (A. Browning); Waning interest from the local running community has forced the organisers to declare this year's race the $10^{\text {th }}$ and the last (Running); High levels of public violence eventually forced the US' occupying forces to take the necessary steps to control and remedy such a deplorable situation (B. Eccleston);

5) іменники, які позначають зовнішні подразники, так звані каузатори: The ever-present threat of Palestinian terrorist attacks has forced the airline to introduce exhaustive security procedures (The Daily Mirror); The crisis has also forced Chancellor Norman Lamont to cut short his holiday as the Bank of England tries to stave off a run on the Pound (The Daily Mirror); Such defaults have forced a large numberof repossessions by bankers and other lenders (The Economist);

6) збірні іменники: When Coca Cola tried to tinker with the taste of Coke an outraged public forced them to return to the original (The Daily Mirror);

7) іменники зі значенням процесів мовленнево-мисленнєвої діяльності людини (knowledge, thought, speech тощо), як-от: Knowledge replacing anger forced silence on Maria (J. Bauling);

8) назви неістот (circumstances, affairs тощо): Circumstances forced her into an evening gown. Perhaps, she decided, she would go back to her hotel and phone Nick from there (J. Tanner);

9) іменники - назви соціуму, установ: Now British Gas have been forced to scrap plans to pull down the 110-year-old hulk (The Daily Mirror);

10) маніфестант (body, soul, heart): Neither of them felt up to leading and their enquiring eyes forced me into the lead (C. \& H. Walker); The Duke's thumbnail had forced a small scar into the map at another crossroads (B. Cornwell).

Детермінуючий чинник може бути внутрішнім, тобто міститися в самому індивіді, як-от: She forced 
her voice to sound normal, though his cool words had felt like something driven against her heart (S. Howard).

Каузативним чинником $є$ хвороба індивіда, його фізичний недуг тощо. Наприклад: Acute back pain forced the Prince to give up polo for a month in June, 1991 (Liverpool Daily Post and Echo); What you must do is lash out with all your available natural weapons until the shock and pain of your attack forces them to let go (S. Romain).

$\mathrm{V}$ реченнях із предикатом примусу каузація спрямована на суб'єкт, який займає позицію об'єкта, і виражається:

1) власними іменами, назвами осіб за професією, родом занять, соціальним статусом тощо: Defences were feverishly reinforced, and unremitting artillery fire forced even the Crown Prince to admit that "our preparations for the attack were considerably interrupted" (A. Horne); The immediate popularity and novelty of ITV's programmes forced the $B B C$ to review its output and made it aware of the need to survive in an increasingly competitive environment (R. Negrine);

2) збірними іменниками: <... >revelations of the poverty-stricken condition of Btitain's tropical empire, especially the West Indies, had forced the British government to take a more visible interest in colonial welfare (K. Tidrick); Within four days, Israel and its lobby in America had forced the US administration to backtrack, abandoning its entire policy (D. McDowell).

3) особовими та зворотними займенниками: It wasn't easy, but she forced herself to go on meeting, that blue gaze without flinching (S. Marton); Fighting an impulse to back awat, Gina forced herself to hold her ground, refusing to let him see how nearness made the hairs on the back on her neck rise in anticipation of conflict (A. Wells);

4) маніфестантами: She said that after he raped her, he forced part of his hand into her, causing pain, and threatened to use the truncheon (Independent); Tautly, she forced her mouth to smile, her head to lift, her tense shoulders to slacken (F. Hendry); Jezrael forced her eyes open (A. Gay).

Прямий каузований об'єкт, що вживається при об'єктному інфінітиві, передається:

1) артефактами: To settle in America they were forced to sign documents stating that they had been persecuted in Russia (The Face);

2) абстрактними іменниками: Those that lie in local spaces having intersections with other spaces will be forced to have an association (A. Medland);

3) назвами організацій, асоціацій, партій, об'єднань тощо, як-от: After a four-year battle, American museums have forced the US Financial Accounting Standards Board (FASB) to abandon its request that museums record their collections on their balance sheets as monetary assets (The Art Newspaper).
У результаті дослідження стверджуємо, що об'єкт-агенс подекуди чинить опір особі, яка змушує. На думку Т. Гівона, «примусове значення» (coercive meaning) лексеми to force передбачає ії використання для опису ситуацій, у яких дія зустрічає опір [10, с. 13]. Отже, семантика лексеми to force вказує на необхідність подолання опору з боку каузованої особи. Значення примусу передусім позначається предикатом to force у формі Past Indefinite або Past Perfect (здебільшого стверджувальній). Це зумовлено тим, що хоч змушувана особа не хоче здійснювати певну дію, чинить опір, проте змушена виконувати небажану дію, тобто примус є здебільшого успішно реалізованим.

Цілком зрозуміло, що предикат примусу to force має негативну конотацію, що пояснює небажаність, неготовність суб'єкта виконувати певну дію, тобто ця дія суперечить його волі, інтересам. Наприклад: I would rather die like a dog than be forced to grovel like one in the name of peace (F. Kippax). Те, що дія $є$ вимушеною, здійснюється під певним тиском, переконливим, настійним примусом, часто вказує контекст. Часто в реченнях із предикатом to force $\epsilon$ лексеми, що вказують на вимушену дію, пояснюють небажання іiі виконання, примушеність суб'єкта до здійснення певної дії, тобто семантичний відтінок внутрішнього протистояння, негативного ставлення до дії може позначатися в контексті за допомогою слів із негативною семантикою: The Kurds $<_{\text {... }}>$ killed her husband and children. They raped her and took her away and forced her to marry one of them (R. Fisk).

Уважаємо, що в англійській мові часто семантика інфінітива при модальному дієслові (наприклад: give up, fear, content, fight) підкреслює вимушений характер дії [8, с. 80]. Наприклад, так може оцінюватися об'єкт, як-от: Torrenian rain forced the abandonment of last Thursday's fixture after just one race (Liverpool Daily Post and Echo); суб'єкт-каузатор: The death of outspoken Conservative MP Richard Holt forced the by-election (Northern Echo); On this highly emotional issue, an extraordinary wave of protest forced the Nazi authorities into retreat (I. Kershaw); Shoplifting and robberies forced the company to spend heavily on expensive security measures (Guardian). Подекуди вимушену дію суб'єкта зумовлює причина, указана в самій структурі речення, наприклад: Fearing to open it, she nevertheless forced herself across the room... (S. Heywood).

$\mathrm{Y}$ реченні The head of another television network, the all-Yugoslav TV service, has also received threats which have forced him to abandon his apartment in Sarajevo (F. Kippax) на вимушеність, нагальність дії вказують лексеми з негативною експресивною оцінкою threat та abandon. 
Цілком зрозуміло, що реалізація вимушеної дії пов'язана 3 подоланням певних труднощів суб'єктом дії. Проблематичність здійснення дії, ії реалізація можуть мати неприємні наслідки для самого виконавця, $\epsilon$ причиною того, що необхідна дія набуває вимушеного, небажаного характеру для суб'єкта дії [8, с. 80]. Наприклад: Spain, exhausted and virtually bankrupt, was forced by the threat of war to give way (M. Anderson).

Висновки й перспективи подальших розробок. Предикат force $\epsilon$ основним засобом вираження семантики примусу. Ситуація примусу включає суб'єкта дії (детермінуючого чинника), те, що зумовлює необхідність виконання дії, об'єкта - того, кого примушують, на кого спрямований вплив детермінуючого чинника; предикат примусу й ознаку, тобто каузовану дію, яка очікується від об'єкта каузованої дії. У ситуації примусу каузований об'єкт здебільшого позначається істотою. Коли каузованим об'єктом є неістота, ситуація наближається до ситуації вимушеності. Такі речення характеризуються негативною семантикою, оскільки дія виконується з примусу, є небажаною та суперечить волі виконавця. Перспективним уважаємо проведення порівняльного аналізу засобів вираження семантики примусу в українській та англійській мовах, аналіз структурно-семантичних моделей речень із предикатами примусу.

\section{ЛІТЕРАТУРА}

1. Великий тлумачний словник сучасної української мови / уклад. і гол. ред. В.Т. Бусел. Київ, $2002.940 \mathrm{c}$.

2. Болдырев Н.Н. Функциональная категоризация английского глагола. Санкт-Петербург ; Тамбов : ТГУ, 1995. 140 с.

3. Дерев'янко О.А. Дебітивність як семантична ознака. Предикат у структурі речення : монографія / за ред. В.І. Кононенка. Київ-Івано-Франківськ-Варшава, 2010. С. 319-347.

4. Кожокина А.В. Структура категории каузативности в пассивной конструкции (на материале анализа английских глаголов to cause и to make. Историческая и сочиально-образовательная мыссль. 2015. № 7. Т. 7. Ч. 2. С. 231-235.

5. Опара А.А. Типологические характеристики финитно-инфинитивных конструкций в разноструктурных языках : автореф. дисс. ... канд. филол. наук : 10.02.20. Волгоград, 2003. $20 \mathrm{c}$.

6. Рейдель А.И. Лексико-грамматическая характеристика каузативных глаголов в предложной конструкции современного английского языка : автореф. дисс. ... кан. филол. наук : 10.02.04. Москва, 1971. 21 с.

7. Романова О.В. Семантические и функциональные особенности глаголов, выражаю- щих концепт ПРИНУЖДЕНИЕ в современном английском языке : дисс. ... канд. филол. наук : 10.02.04. Санкт-Петербург, 2008. 190 с.

8. Тронь О.А. (2001) Семантико-синтаксична структура речень із предикатами дебітивності в сучасній українській мові : дис. ... канд. філол. наук : 10.02.01. Івано-Франківськ, 205 с.

9. Храковский В.С. Очерки по общему и арабскому синтаксису. Москва : Наука, 1973. 289 с.

10. Givon N. English grammar. A Function Based Introduction. Amsterdam : John Benjamins, 1993. Vol. 2. 313 p.

11. Oxford Advanced Learner's Dictionary of Current English (1980) / ed. by A.S. Hornby. Oxford : OUP, 1980. $1037 \mathrm{p}$.

12. Webster Universal College Dictionary. New York: Gramercy Books, 1997. 945 p.

\section{REFERENCES}

1. Velykyi tlumachnyi slovnyk suchasnoi ukrainskoi movy (2002) [Large glossary dictionary of the modern Ukrainian language], uklad. i hol. red. V. T. Busel. Kyiv, 940 p.

2. Boldirev N.N. (1995) Funktsyonalnaia katehoryzatsyia anhlyiskoho hlahola [Functional categorization of an English verb], SPb. Tambov : THU, $140 \mathrm{p}$.

3. Derev'ianko O. A. (2010) Debityvnist yak semantychna oznaka [Debitive modality as a semantic feature]. Predykat u strukturi rechennia: monohrafiia / za red. V. I. Kononenka. KyivIvano-Frankivsk-Varshava, pp. 319-347.

4. Kozhokyna A.V. (2015) Struktura katehoryy kauzatyvnosty $\mathrm{v}$ passyvnoi konstruktsyy (na materyale analyza anhlyiskykh hlaholov to cause, to make) [The structure of the category of causativity in the passive structure (on the basis of the English verbs to cause and to make] Ystorycheskaia y sotsyalno-obrazovatelnaia misl, № 7, v. 7, ch. 2, pp. 231-235.

5. Opara A.A. (2003) Typolohycheskye kharakterystyky fynytno-ynfynytyvnikh konstruktsyi $v$ raznostrukturnikh yazikakh [Typological characteristics of finite-infinitive constructions in multi-structures languages] ( $\mathrm{PhD}$ Thesis) Volhohrad.

6. Reidel A.Y. (1971) Leksyko-hrammatycheskaia kharakterystyka kauzatyvnikh hlaholov v predlozhnoi konstruktsyy sovremennoho anhlyiskoho yazika [The lexical and grammatic characteristics of causative verbs in the prepositional construction of modern English] (PhD Thesis), Moskva.

7. Romanova O.V. (2008) Semantycheskye y funktsyonalnie osobennosty hlaholov, virazhaiushchykh kontsept PRYNUZhDENYE v sovremennom anhlyiskom yazike [Semantic and functional features of the verbs expressing the concept COMPULSION in modern English] (PhD Thesis), Sankt-Peterburh. 
8. Tron O. A. (2001) Semantyko-syntaksychna struktura rechen iz predykatamy debityvnosti $v$ suchasnii ukrainskii movi [Semantic-syntactic structure of the sentences with debitive predicates in modern Ukrainian language] ( $\mathrm{PhD}$ Thesis), Ivano-Frankivsk.

9. Khrakovskyi V.S. (1973) Ocherky po obshchemu $y$ arabskomu syntaksysu [Sketches on the general and Arabian syntax], Moskva : Nauka, 289 p.
10. Givon N. (1993) English grammar. A Function Based Introduction. Amsterdam : John Benjamins, vol. 2, $313 \mathrm{p}$.

11. Oxford Advanced Learner's Dictionary of Current English (1980) ed. by A. S. Hornby. Oxford : OUP, $1037 \mathrm{p}$.

12. Webster Universal College Dictionary (1997) New York : Gramercy Books, 945 p. 